\title{
Water, Soil and Nutrients Losses by Runoff at Hillslope Scale in Agricultural and Pasture Production in Southern Brazil
}

\author{
João Augusto Coblinski ${ }^{1}$, Nerilde Favaretto ${ }^{1}$, Gabriel Democh Goularte ${ }^{1}$, Jeferson Dieckow ${ }^{1}$, Anibal de Moraes ${ }^{2}$ \\ $\&$ Luiz Claudio de Paula Souza ${ }^{1}$ \\ ${ }^{1}$ Department of Soil Science and Agricultural Engineering, Federal University of Paraná, Curitiba, Brazil \\ ${ }^{2}$ Department of Plant Science, Federal University of Paraná, Curitiba, Brazil \\ Correspondence: Nerilde Favaretto, Departamento de Solos e Engenharia Agricola, Universidade Federal do \\ Paraná, Rua dos Funcionários 1540, CEP 80035-050, Curitiba, Paraná, Brazil. Tel: 55-413-350-5638. E-mail: \\ nfavaretto@ufpr.br
}

Received: February 13, $2019 \quad$ Accepted: March 16, $2019 \quad$ Online Published: May 15, 2019

doi:10.5539/jas.v11n6p160 URL: https://doi.org/10.5539/jas.v11n6p160

The research is financed by CNPq-National Council for Scientific and Technological Development of Brazil

\begin{abstract}
Agricultural activity, if not well managed, is an important source of water pollution mainly by surface runoff. The aim of this study was to evaluate losses of water, soil and soluble nutrient (phosphorus, nitrogen and carbon) via runoff in large plots (hillslope from 3,000 to $11,000 \mathrm{~m}^{2}$ ) at slope of 4 to $5 \%$ in annual crops (corn and sunflower) and pasture systems under no-tillage and no-pesticides. The study was carried out at the Canguiri Experimental Farm of the Federal University of Paraná, Southern Brazil, in soil classified as Ferralsol in three systems (crop, pasture and crop-pasture). Soil physical and chemical attributes as well as topographic indices and soil cover were investigated to evaluate the possible impacts of these variables on losses. The runoff was measured after each rainfall event from November 2014 to October 2015. Runoff samples were taken to analyse sediment and nutrients. All systems had low water, soil and nutrients losses compared to no conservative agricultural systems. Higher losses occurred in the annual crops system and were influenced by soil cover, with an annual runoff coefficient of $0.62 \%$ ( $7 \mathrm{~mm}$ of water loss) and an annual soil loss of $2.6 \mathrm{~kg} \mathrm{ha}^{-1}$. The seasonality (winter/summer) did not influence soil, water and nutrient losses.
\end{abstract}

Keywords: runoff, water quality, small catchments, no-tillage, integrated crop-livestock system

\section{Introduction}

Agricultural activity is a greater contributor to the pollution of water resources (Gassman et al., 2006; Ongley, Xiaolan, \& Tao, 2010). Water pollutants (soil particles, nutrients, heavy metals, pesticides, organic matter, pathogens) are primarily transported by runoff (Kay, Edwars, \& Foulger, 2009) and influenced by slope, soil use and management and climatic conditions (Hooda, Edwards, Anderson, \& Miller, 2000; Ma, Li, Zhang, Zheng, \& $\mathrm{Du}, 2011)$.

Phosphorus and nitrogen are essential nutrients for plants, so, extensively applied in agricultural fields, however, in watercourses they cause several detrimental impacts. Phosphorus is associated with eutrophication (Correll, $1998)$ and nitrogen is mostly associated with human health and aquatic life. Nitrate $\left(\mathrm{N}^{-} \mathrm{NO}_{3}{ }^{-}\right)$may involve risks for human health, while ammonium $\left(\mathrm{N}_{-} \mathrm{NH}_{4}{ }^{+}\right)$negatively impacts the ecological balance of water bodies (Chapman, 1998). Another element that influences the water quality is carbon. Soluble organic carbon (COS) present in surface water reacts with free chlorine in domestic water treatment systems and produce trihalomethanes, compounds that may be carcinogenic (Kay et al., 2009). Total organic carbon (TOC) influences the development of microorganisms in the watercourses, thereby altering the odour and increasing the toxicity of the water (M. Libânio, P. A. C. Libânio, \& Costa, 2000). Pesticides can cause environmental damage as well as human and animal health problems (Gevao \& Jones, 2002). In addition to nutrient transport, the soil particles discharged from agricultural areas leads to increased turbidity and sedimentation of rivers and lakes (Ongley, 1996). In Brazil, the threshold values for water pollutants in surface water are stablished by the resolution 
CONAMA 357/2005 (CONAMA, 2005) and in drinking water by resolution 2914/2011 from the Brazilian Health Ministry (Brasil, 2011).

Soil loss depends on several factors, such as land use and management, slope, landform, soil erodibility and rainfall (War \& Cunha, 1995; Leys, Govers, Gillijns, Berckmoes, \& Takken, 2010). The spatial scale also affects the transport of water and sediment. According to Raclot, Bissonais, Louchart, Andrieux, Moussa, and Voltz (2009), soil and water losses are lower in the catchment scale than in the scale of small plots, impeding the estimation of large area losses based on results from small plots. In this context, Van de Giesen, Stomph, and Ridder (2005) stated that the linear extrapolation of the runoff in a small area overestimates the actual flow on surfaces of larger areas.

The food production should be based on agricultural systems that combine productivity with human health and natural resources conservation. Conservative agriculture should be based on minimal soil disturbance, high soil cover and diversification of species. This can slow the rate of runoff and, consequently, decreases soil and nutrient losses (Owens, Malone, Hothem, Starr, \& Lal, 2002; Guadagnin, Bertol, Cassol, \& Amaral, 2005; Endale et al., 2011). The integrated crop-livestock system (ICLS), associated with no-till, is characterised by spatial and temporal interactions on different scales with animals and crops in the same area with vegetation throughout the year (Moraes et al., 2014). Therefore, this system is a viable alternative to the recovery of degraded areas, promoting the stability of the agricultural systems (Bonetti, Paulino, Souza, Carneiro \& Silva, 2015). On a global scale, ICLS is responsible for about $50 \%$ of the entire food production (Carvalho et al., 2014), providing improvements in the soil physical (aggregate stability, porosity and water infiltration), soil biological (microbial activity) and soil chemical (fertility) attributes (Moraes et al., 2014) and reducing soil loss and water rates, thereby contributing to the sustainability of agricultural production.

Delaune and Sij (2012), studying a no-tillage system (NT) with grazing in winter compared to conventional tillage (CT), found greater losses of soil and nutrients (total $\mathrm{P}$ and ammonium-N) in conventional tillage. Guadagnin et al. (2005) also found that conservation agriculture systems, such as the NT, had lower soil, water and nutrients (ammonium-N and nitrate-N) losses than CT.

In this context, the aim of this study was to evaluate the water, soil and nutrients (phosphorus, nitrogen and carbon) losses via runoff in large plots (hillslope) at slope of 4 to $5 \%$ in annual crops (corn and sunflower) and pasture systems under no-tillage and no-pesticides.

\section{Material and Methods}

\subsection{Site Description}

The study was carried out at the Canguiri Experimental Farm of the Federal University of Paraná (UFPR), in soil classified as Ferralsol (FAO-World Reference Base for Soil Resources) according to Sugamosto (2002). According to the Köppen classification, the climate is $\mathrm{Cfb}$, with annual rainfall between 1,400 and 1,800 $\mathrm{mm}$ and average temperature of the coldest month below $18{ }^{\circ} \mathrm{C}$ and the hottest month below $22{ }^{\circ} \mathrm{C}$ (Caviglione, Kiihl, Caramori, \& Oliveira, 2000).

Rainfall volume was obtained from rain gauges installed in each experimental unit. Seasonal data of rainfall were divided into winter (from March 1 to August 31) and summer (from September 1 to February 28).

The experiment with integrated agricultural production systems (crop-livestock-forest integration) under no-tillage consisted of seven treatments distributed in three blocks, totalling 21 large plots (hillslope/small catchments). The experiment began in 2012 (all treatments with winter and summer pastures after corn crop under a conventional system); the annual crops (corn and sunflower) started in the summer 2013/2014 and the grazing was implemented in the summer 2015/2016. This experiment was conducted with no-tillage and no-pesticides application as a law requirement to protect the water quality of the reservoir for domestic supply located near the Canguiri Experimental Farm. The present study was from November 2014 to October 2015. For this study, we selected three systems and one hillslope each with size between 3,000 and $11,000 \mathrm{~m}^{2}$ and slope between 4.3 and $4.6 \%$ (Table 1), described as follows:

- C: crop under no-tillage and no-pesticides; corn (Zea mays) and sunflower (Helianthus annuus) in summer and black oat (Avena strigosa) and ryegrass (Lolium multiflorum) in winter;

- P: pasture under no-tillage and no-pesticides; grass (Panicum maximum Jacq.) in summer and black oat (Avena strigosa) and ryegrass (Lolium multiflorum) in winter; the animal component was not evaluated because grazing was not yet implemented; 
- CP: crop-pasture integration under no-tillage and no-pesticides; three years with grass (Panicum maximum Jacq.) in summer and black oat (Avena strigosa) and ryegrass (Lolium multiflorum) in winter and one year with corn (Zea mays) and sunflower (Helianthus annuus) in summer. The present study was conducted in the third year of the pasture (no summer annual crops yet); the animal component was not evaluated because grazing was not yet implemented.

Table 1. Characteristics of the hillslopes (C: crop; CP: crop-pasture; P: pasture)

\begin{tabular}{llll}
\hline Hillslope & Area $\left(\mathrm{m}^{2}\right)$ & Slope $(\%)$ & Land Cover \\
\hline $\mathrm{C}$ & 3,000 & 4.6 & Crop \\
$\mathrm{CP}$ & 11,000 & 4.3 & Crop-Pasture \\
$\mathrm{P}$ & 9,000 & 4.5 & Pasture \\
\hline
\end{tabular}

\subsection{Soil Chemical and Physical Analyses}

For soil chemical attributes and particle size distribution, samples composed of four subsamples from the upper and four subsamples from the lower position of each hillslopes were collected at four depths (0-5, 5-10, 10-20 and 20-30 cm) in January 2015. Organic carbon was determined by the colorimetric method, while $\mathrm{Ca}^{2+}, \mathrm{Mg}^{2+}$ and $\mathrm{Al}^{3+}$ were extracted with $\mathrm{KCl}$ and $\mathrm{K}^{+}$and $\mathrm{P}$ with Mehlich I. Concentrations of $\mathrm{H}^{+}+\mathrm{Al}^{3+}$ were obtained by pH SMP (Sparks, 1996). Particle size was determined according to the hydrometer method and soil density was evaluated using the ring method (Klute, 1986).

For soil physical attributes, samples were taken from the upper and lower position (of each hillslope) also at four depths $(0-5,5-10,10-20$ and 20-30 cm) in January 2015. For density, porosity and hydraulic conductivity, two undisturbed soil cores (volumetric rings) were collected for each hillslope position and depth. For aggregate stability, one soil monolith was collected in the upper position for each depth. Microporosity was determined at 6 $\mathrm{kPa}$, while total porosity was calculated from bulk and particle density and macroporosity by subtracting total porosity and microporosity. Dry and wet aggregate stability was determined with sieves of 2.0, 1.0, 0.5, 0.25 and $0.105 \mathrm{~mm}$. Saturated hydraulic conductivity was determined via the constant head methodology (Klute, 1986).

\subsection{Topographic Indices}

The topographic indices (LS, profile curvature, plan curvature and MRVBF) were determined with SAGA 2.1.0 software (SAGA, 2013) using topographic maps with a scale of 1:10,000 and contour lines every $5 \mathrm{~m}$.

The LS index (length and slope) indicates the erosion potential (Minella, Merten, \& Ruhoff, 2010), with values ranging from 0 to 4 (low erosive potential), 4 to 6 (medium potential) and 6 to 10 (high erosive potential) (Mansor, Ferreira, Roston, \& Teixeira Filho, 2002).

The profile curvature (vertical curvature) can be described as concave, convex or linear and mainly influences the water flow velocity (Minella et al., 2010), with negative values (concave), positive values (convex), zero values (rectilinear) (Valeriano \& Carvalho, 2003).

The plan curvature (horizontal curvature) can be classified as convergent, divergent or straight and is mainly related to the water flow (Minella et al., 2010), with negative values (convergent), positive values (divergent) and zero values (planar) (Valeriano \& Carvalho, 2003).

The MRVBF index (Index of Multiresolution Valley Bottom Flatness) defines areas of deposition in a landscape (Gallant \& Dowling, 2003), with values above 0.5 (deposition) and below 0.5 (erosion) (Wang \& Laffan, 2009).

The average value, maximum and minimum, and the percentage of occurrence of the topographic index of each hillslope were obtained with the Spatial and Geostatistics tool of the SAGA 2.1.0 software (SAGA, 2013).

\subsection{Soil Cover}

Soil cover was determined by field visual analysis combined with photographic images, obtained from a conventional digital camera. The percentage was indicated by soil cover with vegetation and straw.

\subsection{Runoff Sampling and Analyses}

The drainage area of each hillslope was delimited by optical level and GPS LEICA 900. In the lower part of each large plot (hillslope), a drainage channel was constructed to allow water flow. The base and sides of the channel were covered with grass to avoid erosion and the channel was connected thorough galvanised zinc plates and a 
PVC pipe to a 100-L plastic bucket (with 20 flow dividers), connected to a 60-L plastic bucket (Hudson, 1993). Maximum sampling capacity was $1,300 \mathrm{~L}$.

Runoff sampling was performed for one year (11.01.2014 to 10.30.2015) after each rainfall event with runoff in at least one hillslope (20 events). Runoff volume was measured using graduated devices (bucket and beaker). After homogenisation, runoff samples were taken to analyse sediment and nutrients.

The runoff coefficient was obtained by dividing the runoff volume (accumulated) through the rainfall volume (accumulated).

Soil loss was determined by multiplying the sediment concentration obtained from a $50-\mathrm{mL}$ aliquot dried at $105^{\circ}$ C (APHA, 2005) with the runoff volume.

Soluble nutrients; phosphorus (SP), nitrate- $\mathrm{N}\left(\mathrm{NO}_{3}-\mathrm{N}\right)$, ammonium- $\mathrm{N}\left(\mathrm{NH}_{4}{ }^{+}\right)$and organic carbon (SOC) were analysed from a sample filtered through a membrane of $0.45-\mu \mathrm{m}$ cellulose ester.

Phosphorus was determined by Varian ICP OES (inductively coupled plasma optical emission spectrometer), $\mathrm{NO}_{3}$-N by spectrophotometry at $210 \mathrm{~nm}$ using zinc metal to determine the interference in samples (Heinzmann, Miyazava, \& Pavan, 1984), $\mathrm{NH}_{4}-\mathrm{N}$ by the phenate method using a spectrophotometer at $640 \mathrm{~nm}$ (APHA, 2005) and organic carbon via an Elementar® TOC analyzer Vario-Cube.

\subsection{Statistical Analyses}

Each runoff event was considered a repetition and Tukey's test $(\mathrm{P}<0.05)$ was used to compare means. The principal components analysis (PCA) was applied. All statistical procedures were performed in software R (R Development Core Team, 2015).

\section{Results and Discussion}

\subsection{Soil Attributes and Topographic Indices}

The soil chemical and physical attributes (Tables 2 and 3) did not differ among systems. The experiment began in 2012 but the annual crops were implemented in summer 2013/2014 and the grazing in summer 2015/2016. The soil was sampled in January 2015 (summer 2014/2015), at the second year of the experiment. Differences on these soil attributes among systems are expected at long-term.

In general, there was a similarity among the hillslopes related to plan and profile curvature (Tables 4 and 5). Also, the hillslopes showed low LS index values, suggesting a low erosive potential, and a high MRVBF index, indicating a high susceptibly to soil deposition (Tables 4 and 5).

Therefore, the results from soil analyses (soil and chemical attributes) and topographic indices (PLC, PRC, MRVBR and LS) support the statement that the differences in water, soil and nutrients losses among the systems will be due to land use and management.

Table 2. Weighted average $(0-30 \mathrm{~cm}$ depth) of the soil chemical attributes of the hillslopes (C: crop; CP: crop-pasture; P: pasture), Pinhais, PR

\begin{tabular}{|c|c|c|c|c|c|c|c|c|c|}
\hline Hillslope & $\mathrm{pH} \mathrm{CaCl}{ }_{2}$ & $\mathrm{pH}$ SMP & $\mathrm{Al}$ & $\mathrm{H}+\mathrm{Al}$ & $\mathrm{Ca}$ & $\mathrm{Mg}$ & K & $\mathrm{P}$ & $\mathrm{C}$ \\
\hline & & & $---\cdot$ & ----- & $\mathrm{cmol}$ & --- & ----------- & $\mathrm{mg} \mathrm{kg}^{-1}$ & $\mathrm{~g} \mathrm{dm}^{-3}$ \\
\hline $\mathrm{C}$ & 5.6 & 6.0 & 0.1 & 5.1 & 7.9 & 3.8 & 0.2 & 4.6 & 41.2 \\
\hline $\mathrm{CP}$ & 5.6 & 5.9 & 0.1 & 5.7 & 8.7 & 4.0 & 0.2 & 4.1 & 54.4 \\
\hline $\mathrm{P}$ & 5.4 & 5.8 & 0.2 & 5.8 & 7.2 & 3.6 & 0.4 & 5.6 & 49.0 \\
\hline
\end{tabular}

Table 3. Weighted average (0-30 $\mathrm{cm}$ depth) of the physical attributes of the hillslopes (C: crop; CP: crop-pasture; P: pasture), Pinhais, PR

\begin{tabular}{|c|c|c|c|c|c|c|c|c|c|c|}
\hline \multirow{2}{*}{ Hillslope } & \multirow{2}{*}{ Ds } & \multirow{2}{*}{$\mathrm{Pt}$} & \multirow{2}{*}{ Mic } & \multirow{2}{*}{ Mac } & \multirow{2}{*}{ Ksat } & \multirow{2}{*}{ MWDd } & \multirow{2}{*}{ MWDw } & \multicolumn{3}{|c|}{ Particle Distribution (\%) } \\
\hline & & & & & & & & Clay & Silt & Sand \\
\hline & $\mathrm{Mg} \mathrm{m}^{-3}$ & --- & $----\%$ & ------- & $\mathrm{mm} \mathrm{h}^{-1}$ & ----------- & m ---------. & & & \\
\hline $\mathrm{C}$ & 1.3 & 55 & 45 & 10 & 99.0 & 2.1 & 1.7 & 55.4 & 9.0 & 35.6 \\
\hline $\mathrm{CP}$ & 1.2 & 56 & 44 & 8 & 74.3 & 2.0 & 1.7 & 64.6 & 9.8 & 25.6 \\
\hline $\mathrm{P}$ & 1.2 & 57 & 45 & 12 & 151.4 & 2.0 & 1.9 & 62.9 & 11.5 & 25.7 \\
\hline
\end{tabular}

Note. Ds: Soil density, Pt: Total porosity, Mic: Microporosity, Mac: Macroporosity, Ksat: Saturated hydraulic conductivity, MWDd: Mean weighted diameter (dry), MWDw: Mean weighted diameter (wet). 
Table 4. Minimum (Min), medium (Med) and maximum (Max) values of topographic indices in the hillslopes (C: crop; CP: crop-pasture; P: pasture)

\begin{tabular}{|c|c|c|c|c|c|c|c|c|c|c|c|c|}
\hline \multirow{2}{*}{ Hillslope } & \multicolumn{3}{|c|}{ PLC } & \multicolumn{3}{|c|}{ PRC } & \multicolumn{3}{|c|}{ MRVBR } & \multicolumn{3}{|c|}{ LS } \\
\hline & Min & Med & Max & Min & Med & Max & Min & Med & Max & Min & Med & Max \\
\hline $\mathrm{C}$ & -0.002 & -0.0001 & 0.002 & -0.004 & 0.0003 & 0.007 & 0.521 & 1.135 & 1.554 & 0.251 & 0.544 & 1.109 \\
\hline $\mathrm{CP}$ & -0.003 & 0.0006 & 0.006 & -0.006 & -0.0002 & 0.010 & 0.162 & 1.490 & 3.843 & 0.010 & 0.319 & 0.958 \\
\hline P & -0.012 & 0.0001 & 0.008 & -0.014 & 0.0002 & 0.014 & 0.006 & 1.336 & 3.979 & 0.000 & 0.330 & 1.436 \\
\hline
\end{tabular}

Note. PLC: Plan curvature (negative: convergent; positive: divergent; null: rectilinear); PRC: Profile curvature (negative: concave; positive: convex; null: rectilinear); MRVBF: Multiresolution Index of Valley Bottom Flatness (Erosion and sedimentation potential; < 0.5: erosion; > 0.5: deposition); LS: Length and Slope (Erosion potential; 0-4: low; 4-6: Medium; 6-10: high).

Table 5. Topographic indices (\%) in the hillslopes (C-crop; CP- crop-pasture; P-pasture)

\begin{tabular}{|c|c|c|c|c|c|c|c|c|}
\hline \multirow{2}{*}{ Hillslope } & \multicolumn{2}{|c|}{ PLC } & \multicolumn{2}{|c|}{ PRC } & \multicolumn{2}{|c|}{ MRVBF } & \multicolumn{2}{|c|}{ LS } \\
\hline & conv & div & conc & convx & erosion & deposition & low & high \\
\hline & & - & & & 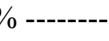 & & & \\
\hline $\mathrm{C}$ & 64 & 36 & 47 & 53 & 0 & 100 & 100 & 0 \\
\hline $\mathrm{CP}$ & 42 & 58 & 54 & 46 & 8 & 92 & 100 & 0 \\
\hline $\mathrm{P}$ & 50 & 50 & 52 & 48 & 11 & 89 & 100 & 0 \\
\hline
\end{tabular}

Note. PLC: Plan curvature (conv: convergent; div: divergent); PRC: Profile curvature (conc: concave; convx: convex); MRVBF: Erosion and sedimentation potential; LS: Erosion potential.

\subsection{Water and Soil Losses}

Accumulated water loss (runoff) varied from 0.5 to $7.0 \mathrm{~mm} \mathrm{year}^{-1}$, with a runoff coefficient from 0.04 to $0.62 \%$; therefore, less than $1 \%$ of the rainfall was lost through runoff. The crop hillslope (corn and sunflower) had a higher water loss $\left(7 \mathrm{~mm} \mathrm{year}^{-1}\right)$ (Table 6); however, this is a low value compared to that in intensive production systems (Cogo, Levien, \& Schwarz, 2003). Ramos et al. (2014), in a study with three hillslopes (1,600 to 3,200 $\mathrm{m}^{2}$ ) and different land uses (forest, organic horticulture and conventional horticulture), also found runoff coefficients below 1\%. Similarly, Shiptalo, Dick, and Edwards (2000), in a study with small catchments (conventional and no-tillage with corn), found runoff coefficient less than $1 \%$ at the no-tillage and $17 \%$ in the conventional system.

Water losses during the sampling period (one year) were also higher in the crop hillslope, with 17 rainfall events with runoff (four major events on 11 and 16 March $2015(1.14$ and $1.00 \mathrm{~mm}$ ) and on 12 and 17 July with 1.24 and $1.30 \mathrm{~mm}$; Figure 1). These higher losses were possibly due to the lower soil cover (final cicle of corn and sunflower in March and sowing of oats and ryegrass in late June). In the other hillslopes, loss rates were even lower compared with the crop, (13 rainfall events with runoff on the $\mathrm{CP}$ and 10 on the $\mathrm{P}$ ), reaching a maximum of $0.15 \mathrm{~mm}$ per event. The soil cover on the hillslopes with pasture (CP and $\mathrm{P})$ during the monitoring period was above $60 \%$ on average. The hillslope with crop had an average loss of $0.35 \mathrm{~mm}$ in the evaluated period, which was significantly higher than that of the other hillslopes (Table 6).

The greatest soil loss occurred in the crop hillslope (14 times greater than CP and P) (Table 6). Most of the soil loss occurred at four events (11 and 16 March and 12 and 17 July; Figure 1). These losses accounted for $71 \%$ of the annual loss $\left(2.6 \mathrm{~kg} \mathrm{ha}^{-1} \mathrm{year}^{-1}\right.$; Table 6$)$. The greater soil loss in the crop system was related to the lower soil cover (Basic, Kisic, Butorac, Nestroy, \& Mesic, 2001). With an average loss of $0.13 \mathrm{~kg} \mathrm{ha}^{-1}$ event $^{-1}$, the crop hillslope showed significantly greater losses compared to the other hillslopes (Table 6). According to Derpsch, Roth, Sidiras, and Köpke (1991), the average soil loss in no-tillage systems in Paraná State, Brazil, is 6.9 t ha $^{-1}$ year ${ }^{-1}$. Merten, Araújo, Biscaia, Barbosa and Conte (2015), in a study on small plots (up to $77 \mathrm{~m}^{2}$ ) and large plots (up to $10,000 \mathrm{~m}^{2}$ ) in Paraná, showed that no-tillage systems had lower soil and water losses than areas with some kind of soil disturbance, and the average soil loss (13 years of investigation) was $0.05 \mathrm{tha}^{-1}$ year $^{-1}$ in large plots and $0.4 \mathrm{t} \mathrm{ha}^{-1}$ year $^{-1}$ in small plots. Compared to these data, our values $\left(0.0005\right.$ to $0.0026 \mathrm{t} \mathrm{ha}^{-1}$ year $\left.{ }^{-1}\right)$ are extremely low.

Sediment concentration values ranged from 0.07 to $0.12 \mathrm{~g} \mathrm{~L}^{-1}$ (Table 6). Vadas et al. (2015), in a study on pastures and animal grazing, found an average sediment concentration of $0.20 \mathrm{~g} \mathrm{~L}^{-1}$; the authors ascribed the low values to the high soil cover. 
Rainfall was well distributed among the winter and summer seasons (on average, $606 \mathrm{~mm}$ in summer and 535 $\mathrm{mm}$ in winter), which contributed to the non-occurrence of seasonality (winter/summer) effects on water and soil losses.

Table 6. Rainfall, water loss, runoff coefficient (RC), soil loss and sediment concentration (SED) in the hillslopes (C: crop; CP: crop-pasture; P: pasture)

\begin{tabular}{|c|c|c|c|c|c|c|c|c|c|}
\hline \multirow{2}{*}{ Hillslope } & \multirow{2}{*}{$\begin{array}{l}\text { Rainfall } \\
\text { Annual }\end{array}$} & \multicolumn{4}{|c|}{ Water Loss } & \multirow{2}{*}{$\mathrm{RC}$} & \multicolumn{2}{|c|}{ Soil Loss } & \multirow{2}{*}{$\begin{array}{l}\text { SED } \\
\text { Mean }^{1}\end{array}$} \\
\hline & & Winter & Summer & Annual & Mean $^{1}$ & & $\overline{\text { Annual }}$ & Mean $^{1}$ & \\
\hline & --- & - & ---- mr & --- & 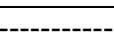 & $\%$ & - ------ & $h^{-1}-\cdots$ & $\mathrm{g} \mathrm{L}^{-1}$ \\
\hline $\mathrm{C}$ & 1134 & 3.0 & 3.9 & 7.0 & $0.35 \mathrm{a}$ & 0.62 & 2.6 & $0.13 \mathrm{a}$ & $0.12 \mathrm{a}$ \\
\hline $\mathrm{CP}$ & 1135 & 0.1 & 0.5 & 0.6 & $0.02 \mathrm{~b}$ & 0.05 & 0.7 & $0.03 \mathrm{~b}$ & $0.07 \mathrm{a}$ \\
\hline $\mathrm{P}$ & 1140 & 0.1 & 0.3 & 0.5 & $0.02 \mathrm{~b}$ & 0.04 & 0.5 & $0.03 \mathrm{~b}$ & $0.07 \mathrm{a}$ \\
\hline
\end{tabular}

Note. ${ }^{1}$ Means (by rainfall event) followed by the same letter in the column are not significantly different by Tukey's test $(\mathrm{P}<0.05)$.
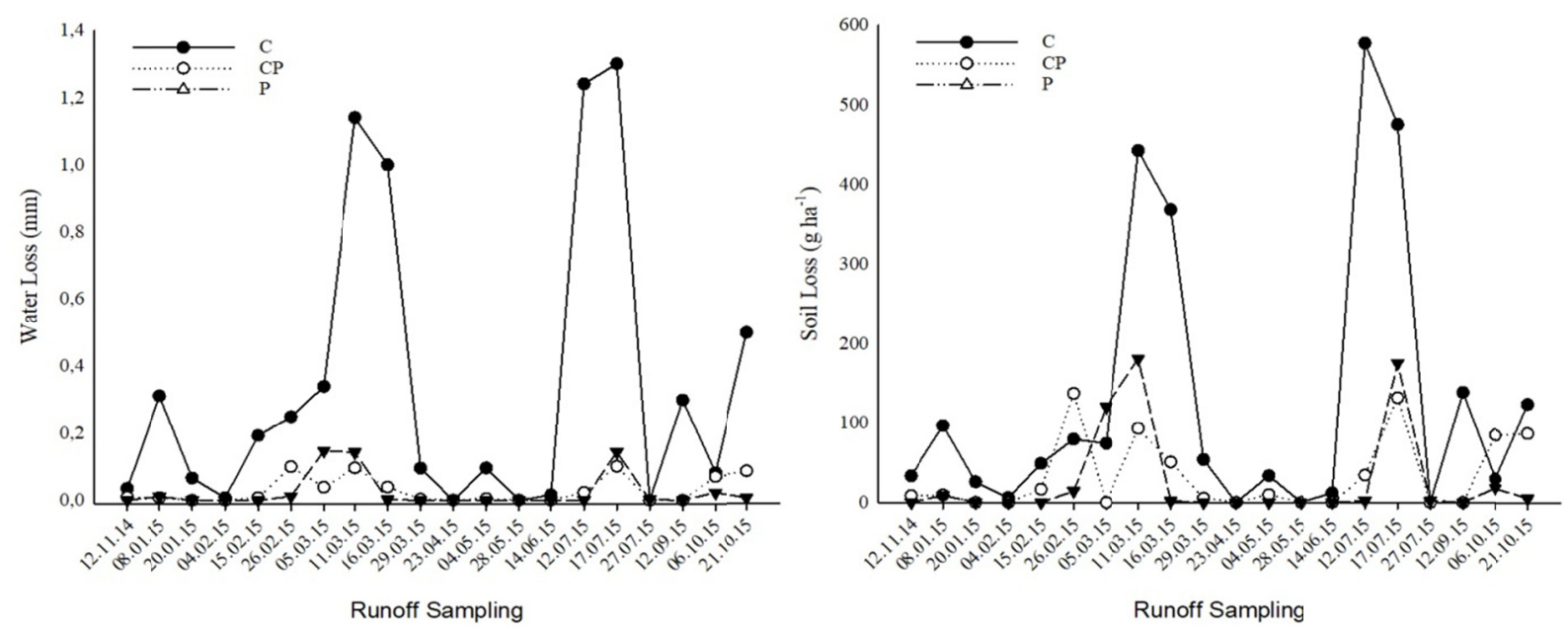

Figure 1. Water $(\mathrm{mm})$ and soil loss $\left(\mathrm{g} \mathrm{ha}^{-1}\right)$ via surface runoff by rainfall event in the hillslopes (C: crop; CP: crop-pasture; P: pasture)

\subsection{Nutrient Concentration and Losses}

The hillslope with crop (C) was significantly different from the pasture hillslopes for ammonium $\left(\mathrm{NH}_{4}-\mathrm{N}\right)$ concentrations in the runoff, by rainfall events (Table 7). For the nutrient losses by rainfall events $\left(\mathrm{g}^{-1} \mathrm{ha}^{-1}\right.$, we observed higher values of nitrate $\left(\mathrm{NO}_{3}-\mathrm{N}\right)$, ammonium $\left(\mathrm{NH}_{4}-\mathrm{N}\right)$ and soluble organic carbon (SOC) (Table 7).

The annual mean weighted concentration of soluble phosphorus (SP) was higher in the hillslopes with pasture (P and CP) $\left(0.3\right.$ to $\left.0.4 \mathrm{mg} \mathrm{L}^{-1}\right)$ compared to the hillslope with crop $\left(0.2 \mathrm{mg} \mathrm{L}^{-1}\right)$ (Table 8$)$. However, the annual SP losses (Table 8 ) from our study (1.4 to $2.9 \mathrm{~g} \mathrm{ha}^{-1}$ ) can be considered low (less than $0.5 \%$ of the applied SP), considering that annual fertilisation in pasture can be greater than $50 \mathrm{~kg} \mathrm{P}^{-1}$ year $^{-1}$.

The higher mean weighted concentration of SP in pasture hillslopes (CP and P) were possibly due to the higher amount of $\mathrm{P}$ applied via rock phosphate. Vadas, Busch, Powell, and Brink (2015) found even higher concentrations of SP (1.5 mg L $\left.\mathrm{m}^{-1}\right)$ in grazed pastures. Owino, Owido, and Chemelil (2006), in a crop system under no-tillage, found average SP concentrations from 0.35 to $1.30 \mathrm{mg} \mathrm{L}^{-1}$. According to CONAMA $357 / 2005$ (CONAMA, 2005), $0.02 \mathrm{mg} \mathrm{L}^{-1}$ of total $\mathrm{P}$ is the threshold value in lentic aquatic environments, while $0.1 \mathrm{mg} \mathrm{L}^{-1}$ is the threshold for lotic aquatic environments. However, the CONAMA resolution 357/2005 considers the P concentration threshold in the aquatic environment, which makes it difficult to compare potential pollutants via runoff which may or may not reach the watercourses.

Nitrogen is an essential nutrient for plant growth; however, in water, it can be associated with human health problems $\left(\mathrm{NO}_{3}-\mathrm{N}\right)$ and pose a potential risk for aquatic life $\left(\mathrm{NH}_{4}-\mathrm{N}\right)$. Soluble nitrogen can be transported from the soil to the water via subsurface flow and surface runoff (Chapman, 1998; Smith, Warnemuende, Huang, \& 
Heathman, 2007). However, due to its high mobility in the soil, soluble nitrogen losses via nitrate are expected to be low (Yang et al., 2009; Shan et al., 2015).

The mean weighted concentration of $\mathrm{NO}_{3}-\mathrm{N}$ was low in all hillslopes (1.1 to $1.4 \mathrm{mg} \mathrm{L}^{-1}$ ) (Table 8). Vadas and Powell (2013) also observed low values; $80 \%$ of $\mathrm{NO}_{3}-\mathrm{N}$ concentrations were lower than $5 \mathrm{mg} \mathrm{L}^{-1}$ in pasture treatments. According to CONAMA 357/2005 (CONAMA, 2005) and the Brazilian Health Ministry (Brasil, 2011), the maximum threshold value of $\mathrm{NO}_{3}-\mathrm{N}$ in water is $10 \mathrm{mg} \mathrm{L}^{-1}$.

The mean weighted concentrations of $\mathrm{NH}_{4}-\mathrm{N}$ also were low (below $0.6 \mathrm{mg} \mathrm{L}^{-1}$ ) (Table 8) and even lower that the findings observed by Vadas and Powell (2013) (1.8 $\mathrm{mg} \mathrm{L}^{-1}$ on hillslopes of up to 4,000 $\mathrm{m}^{2}$ with grazing pasture). The nitrogen dynamics is greatly dependent of the fertiliser management and the biological activity. Considering the rainfall events, the highest concentration of $\mathrm{NH}_{4}-\mathrm{N}\left(12.67 \mathrm{mg} \mathrm{L}^{-1}\right)$ was observed for the crop hillslope at the beginning of the experiment (one month after fertilisation $\left(450 \mathrm{~kg} \mathrm{ha}^{-1}\right.$ of urea) and two months after crop sowing ( $25 \%$ soil cover). The hillslopes with pasture had even lower concentrations compared to that with crop, which can be explained by the increased soil cover and by the increased absorption by vegetation (Povilaitis, Sileika, Deelstra, Gaigalis, \& Baigys, 2014).

The highest cumulative loss of $\mathrm{NO}_{3}-\mathrm{N}\left(30.8 \mathrm{~g} \mathrm{ha}^{-1}\right.$ year $\left.^{-1}\right)$ and $\mathrm{NH}_{4}-\mathrm{N}\left(14.2 \mathrm{~g} \mathrm{ha}^{-1}\right.$ year $\left.{ }^{-1}\right)$ occurred in the crop hillslope (Table 8). However, these values are extremely low, considering that in agricultural production, doses above $150 \mathrm{~kg} \mathrm{ha}^{-1}$ year $^{-1}$ of $\mathrm{N}$ are usually applied. In our study, we applied $200 \mathrm{~kg} \mathrm{ha}^{-1}$ year $^{-1}$ of nitrogen in pastures as well as in corn and sunflower crops.

The mean weighted concentrations of soluble organic carbon (SOC) were greater in pastures hillslopes (CP and P), but the annual loss of soluble organic carbon was greater in the crop hillslope (Table 8), even with a lower mean weighted SOC concentration; these results agree with the findings of Veum, Goyne, Motavalli, and Udawatta (2009) and Endale et al. (2011) and confirm that SOC losses tend to be higher in systems with higher amounts of straw accumulated on the soil surface (Kindler et al., 2011; Janeaua et al., 2014).

Table 7. Mean concentration $\left(\mathrm{mg} \mathrm{L}^{-1}\right)$ and loss $\left(\mathrm{g} \mathrm{ha}^{-1}\right)$ by rainfall events of nitrate, ammonium, phosphorus and carbon on the hillslopes (C: crop; CP: crop-pasture; P: pasture)

\begin{tabular}{|c|c|c|c|c|}
\hline Hillslope & $\mathrm{NO}_{3}-\mathrm{N}^{1}$ & $\mathrm{NH}_{4}^{+}-\mathrm{N}^{1}$ & $\mathrm{SP}^{1}$ & $\mathrm{SOC}^{1}$ \\
\hline & -------- & 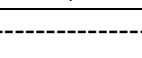 & $\mathrm{L}^{-1}-\cdots$ & \\
\hline C & $1.3 \mathrm{a}$ & $2.0 \mathrm{a}$ & $0.2 \mathrm{a}$ & $14.5 \mathrm{a}$ \\
\hline $\mathrm{CP}$ & $0.7 \mathrm{a}$ & $0.9 \mathrm{~b}$ & $0.3 \mathrm{a}$ & $11.9 \mathrm{a}$ \\
\hline $\mathrm{P}$ & $0.5 \mathrm{a}$ & $0.7 \mathrm{~b}$ & $0.2 \mathrm{a}$ & $8.1 \mathrm{a}$ \\
\hline C & $1.5 \mathrm{a}$ & $0.7 \mathrm{a}$ & $0.1 \mathrm{a}$ & $17.7 \mathrm{a}$ \\
\hline $\mathrm{CP}$ & $0.4 \mathrm{~b}$ & $0.2 \mathrm{~b}$ & $0.1 \mathrm{a}$ & $6.0 \mathrm{~b}$ \\
\hline $\mathrm{P}$ & $0.3 \mathrm{~b}$ & $0.1 \mathrm{~b}$ & $0.1 \mathrm{a}$ & $3.8 \mathrm{~b}$ \\
\hline
\end{tabular}

Note. $\mathrm{NO}_{3}{ }^{-}-\mathrm{N}$ : nitrate; $\mathrm{NH}_{4}{ }^{+}-\mathrm{N}$ : ammonium; SP: soluble phosphorus; SOC: soluble organic carbon.

${ }^{1}$ Means (by rainfall event) followed by the same letter in the column are not significantly different by Tukey's test $(\mathrm{P}<0.05)$.

Table 8. Mean annual weighted concentration $\left(\mathrm{mg} \mathrm{L}^{-1}\right)$ and accumulated loss $\left(\mathrm{g} \mathrm{ha}^{-1}\right.$ year $\left.{ }^{-1}\right)$ of nitrate, ammonium, phosphorus and carbon on the hillslopes (C: crop; $\mathrm{CP}$ : crop-pasture; P: pasture)

\begin{tabular}{|c|c|c|c|c|}
\hline Hillslope & $\mathrm{NO}_{3}{ }^{-}-\mathrm{N}$ & $\mathrm{NH}_{4}{ }^{+}-\mathrm{N}$ & SP & SOC \\
\hline & \multicolumn{4}{|c|}{---o- } \\
\hline $\mathrm{C}$ & 1.4 & 0.6 & 0.2 & 16.0 \\
\hline $\mathrm{CP}$ & 1.1 & 0.6 & 0.4 & 18.1 \\
\hline \multirow[t]{2}{*}{$\mathrm{P}$} & 1.1 & 0.5 & 0.3 & 16.3 \\
\hline & \multicolumn{4}{|l|}{---} \\
\hline $\mathrm{C}$ & 30.8 & 14.2 & 2.9 & 353.6 \\
\hline $\mathrm{CP}$ & 7.3 & 4.3 & 2.1 & 120.7 \\
\hline $\mathrm{P}$ & 5.2 & 2.3 & 1.4 & 75.1 \\
\hline
\end{tabular}

Note. $\mathrm{NO}_{3}{ }^{-}-\mathrm{N}$ : nitrate; $\mathrm{NH}_{4}{ }^{+}-\mathrm{N}$ : ammonium; SP: soluble phosphorus; $\mathrm{SOC}$ : soluble organic carbon. 
In general, there was a positive relationship between nutrient loss and water loss, which was expected considering that the transport of soluble nutrients from soil, plant and straw depends on the water loss (Richardson \& King, 1995; Mcdowell \& Sharpley, 2001; Guadagnin et al., 2005; Bertol, Rizzi, Bertol, \& Roloff, 2007; Deelstra et al., 2014).

The results of the principal components analysis (Figure 2) shows that soil cover (vegetation and straw) had an inverse relation with the losses (lower soil cover causes higher losses), but no effect on concentration. Agriculture conservative systems with minimal soil disturbance, high soil cover and diversification of species will improve the physical, chemical and biological soil quality (Volk, Cogo, \& Streck, 2004; Armand, Bockstaller, Auzet, \& Dijk, 2009), resulting in lower soil, water and nutrient losses.

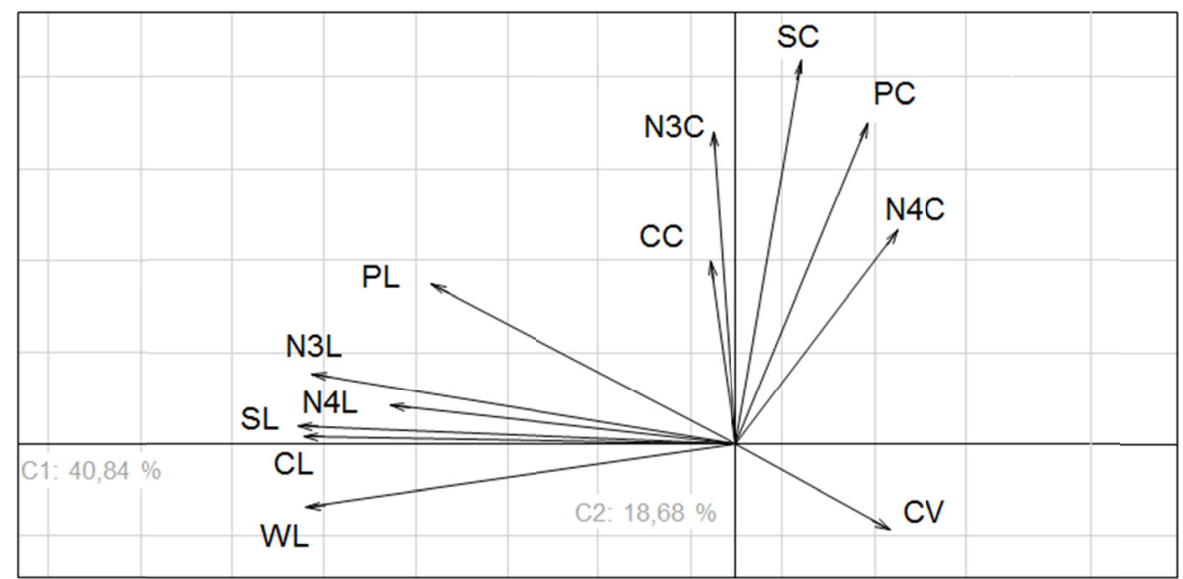

Figure 2. Principal component analysis. WL: water loss; SL: soil loss; CL: carbon loss; N3L: nitrate loss; N4L: ammonium loss; PL: phosphorus loss; SC: sediment concentration; CC: carbon concentration; N3C: nitrate concentration; PC: phosphorus concentration; N4C: ammonium concentration; CV: vegetation cover

\section{Conclusions}

Losses of water, soil and nutrients were low in the crop system with corn and sunflower under no-tillage (surface runoff of $7 \mathrm{~mm}_{\text {year }}{ }^{-1}$ and soil loss of $2.6 \mathrm{~kg} \mathrm{ha}^{-1}$ year $^{-1}$ ) and even lower in the pasture system, which means that it is possible to produce food (grain and meat) and protect the environment and the human health using conservative agriculture (minimal soil disturbance, high soil cover, diversification of species and no-pesticides). Soil cover significantly affected water, soil and nutrient losses, while the different seasons (winter/summer) had no impact on losses.

\section{References}

APHA (American Public Health Association American Water Works Association). (2005). Water Environment Federation. Standard Methods for the Examination of Water and Wastewater. Washington.

Armand, R., Bockstaller, C., Auzet, A. V., \& Dijk, P. V. (2009). Runoff generation related to intra-field soil surface characteristics variability Application to conservation tillage context. Soil and Tillage Research, 102, 27-37. https://doi.org/10.1016/j.still.2008.07.009

Basic, F., Kisic, I., Butorac, A., Nestroy, O., \& Mesic, M. (2001). Runoff and soil loss under different tillage methods on stagnic luvisols in central Croatia. Soil and Tillage Research, 62, 145-151. https://doi.org/ 10.1016/S0167-1987(01)00214-8

Bertol, O. J., Rizzi, N. E., Bertol, I., \& Roloff, G. (2007). Perdas de solo e água e qualidade do escoamento superficial associadas à erosão entre sulcos em área cultivada sob semeadura direta e submetida às adubações mineral e orgânica. Revista Brasileira de Ciência do Solo, 31, 781-792. https://doi.org/10.1590/ S0100-06832007000400018

Bonetti, J. A., Paulino, H. B., Souza, E. D., Carneiro, M. A. C., \& Silva, G. N. (2015). Influência do sistema integrado de produção agropecuária no solo e na produtividade de soja e braquiária. Pesquisa Agropecuária Tropical, 45, 104-112. https://doi.org/10.1590/1983-40632015v4529625

Brasil, Ministério da Saúde. (2011). Portaria 2.914, de 12 de dezembro de 2011. Brasília. 
Carvalho, P. C. F., Moraes, A., Pontes, L. S., Anghinoni, I., Sulc, R. M., \& Batello, C. (2014). Definições e terminologias para sistema integrado de produção agropecuária. Revista Ciência Agronômica, 45, 1040-1046. https://doi.org/10.1590/S1806-66902014000500020

Caviglione, J. H., Kiihl, L. R. B., Caramori, P. H., \& Oliveira, D. (2000). Cartas climáticas do Paraná. Iapar, Londrina.

Chapman, D. (1998). Water quality assessments: A guide to the use of biota, sediment and water in environmental monitoring. Spon Press, London.

Cogo, N. P., Levien, R., \& Schwarz, R. A. (2003). Perda de solo e água por erosão hídrica influenciadas por métodos de preparo, classes de declive e níveis de fertilidade do solo. Revista Brasileira de Ciência do Solo, 27, 746-753. https://doi.org/10.1590/S0100-06832003000400019

CONAMA (Conselho Nacional do Meio Ambiente). (2005). Resolução CONAMA nº 357/2005 (in Portuguese). Brasília, Diário Oficial da União.

Correll, D. L. (1998). The role phosphorus in the eutrophication of receiving waters: A review. Journal of Environmental Quality, 27, 261-266. https://doi.org/10.2134/jeq1998.272261x

Deelstra, J., Lital, A., Povilaitis, A., Kyllmar, K., Greipsland, I., Mathiesen, G. B., ... Lagzdins, A. (2014). Hydrological pathways and nitrogen runoff in agricultural dominated catchments in Nordic and Baltic countries. Agriculture, Ecosystems \& Environment, 198, 65-73. https://doi.org/10.1016/j.agee.2014.06.007

Delaune, P. B., \& Sij, J. W. (2012). Impact of tillage on runoff in long term no-till wheat systems. Soil and Tillage Research, 124, 32-35. https://doi.org/10.1016/j.still.2012.04.009

Derpsch, R., Roth, C. H., Sidiras, N., \& Köpke, U. (1991). Controle da erosão no Paraná, Brasil: Sistemas de cobertura do solo, plantio direto e preparo conservacionista do solo. IAPAR, Londrina.

Endale, D. M., Fisher, D. S., Owens, L. B., Jenkins, M. B., Schomberg, H. H., Tebes-Stevens, C. L., \& Bonta, J. V. (2011). Runoff water quality during drought in a zero-order Georgia Piedmont pasture: Nitrogen and total organic carbono. Journal of Environmental Quaityl, 40, 969-979. https://doi.org/10.2134/jeq2010.0411

Gallant, J. C., \& Dowling, T. I. (2003). A multiresolution index of valley bottom flatness for mapping depositional areas. Water Resources Research, 39, 13-47. https://doi.org/10.1029/2002WR001426

Gassman, P. W., Osei, E., Saleh, A., Rodecap, J., Norvell, S., \& Williams, J. (2006). Alternative practices for sediment and nutrient loss control on livestock farms in northeast Iowa. Agriculture, Ecosystems \& Environment, 117, 135-144. https://doi.org/10.1016/j.agee.2006.03.030

Gevao, B, \& Jones, K. C. (2002). Pestices and persistente organic pollutants. In P. M. Haygarth, \& S. C. Jarvis (Eds.), Agriculture, hydrology and water quality (pp. 83-106). CABI Publishing, Devon, UK. https://doi.org/10.1079/9780851995458.0083

Guadagnin, J. C., Bertol, I., Cassol, P. S., \& Amaral, A. J. (2005). Perda de solo, água e nitrogênio por erosão hídrica em diferentes sistemas de manejo (in Portuguese). Revista Brasileira de Ciência do Solo, 29, 277-286. https://doi.org/10.1590/S0100-06832005000200013

Heinzmann, F. X., Miyazava, M., \& Pavan, M. A. (1984). Determinação de nitrato por espectrofotometria de absorção ultravioleta. Revista Brasileira de Ciência do Solo, 8, 159-163.

Hooda, P. S., Edwards, A. C., Anderson, H. A., \& Miller, A. (2000). A review of water quality concerns in livestock farming areas. Science of Total Environment, 250, 143-167. https://doi.org/10.1016/S0048-9697 (00)00373-9

Hudson, N. W. (1993). Field measurement of soil erosion and runoff. Food \& Agriculture Organization, Rome.

Janeaua, J. L., Gillard, L. C., Grellier, S., Jouqueta, P., Quynh, L. T. P., Minhg, L. T. N., ... Rochelle-Newalla, E. (2014). Soil erosion, dissolved organic carbon and nutrient losses under different land use systems in a small catchment in northern Vietnam. Agricultural Water Management, 146, 314-323. https://doi.org/ 10.1016/j.agwat.2014.09.006

Kay, P., Edwards, A. C., \& Foulger, M. (2009). A review of the efficacy of conteporary agricultural stewardship measures for ameliorating water pollution problems of key concern to the UK water industry. Agricultural Systems, 99, 67-75. https://doi.org/10.1016/j.agsy.2008.10.006 
Kindler, R., Siemens, J., Kaiser, K., Walmsley, D. C., Bernhofer, C., Buchmann, N., ... Kaupenjohann, M. (2011). Dissolved carbon leaching from soil is a crucial component of the net ecosystem carbon balance. Global Change Biology, 17, 1167-1185. https://doi.org/10.1111/j.1365-2486.2010.02282

Klute, A. (1986). Methods of Soil Analysis (Part 1). Physical and Mineralogical Methods. SSSA, Madison.

Leys, A., Govers, G., Gillijns, K., Berckmoes, E., \& Takken, I. (2010). Scale effects on runoff and erosion losses from arable land under conservation and conventional tillage: The role of residue cover. Journal of Hydrology, 390, 143-154. https://doi.org/10.1016/j.jhydrol.2010.06.034

Libânio, M., Libânio, P. A. C., \& Costa, B. M. P. (2000). Avaliação da relevância do carbono orgânico total como parâmetro de caracterização de águas de abastecimento. Revista Brasileira de Recursos Hídricos, 5, 41-55. https://doi.org/10.21168/rbrh.v5n4.p41-55

Ma, X., Li, Y., Zhang, M., Zheng, F., \& Du, S. (2011). Assessment and analysis of non-point source nitrogen and phosphorus loads in the three gorges reservoir area of Hubei province, China. Science Total Environment, 412, 154-161. https://doi.org/10.1016/j.scitotenv.2011.09.034

Mansor, M. T. C., Ferreira, L., Roston, D. M., \& Teixeira Filho, J. (2002). Parâmetro para avaliação do potencial de risco de erosão. Anais do I Simpósio regional de geoprocessamento e sensoriamento remote (pp. 17-18). Retrieved from http://www.cpatc.embrapa.br/labgeo/srgsr1/pdfs/poster12.pdf

Mcdowell, R. W., \& Sharpley, A. N. (2001). Soil phosphorus fractions in solution: Influence of fertiliser and manure, filtration and method of determination. Chemosphere, 45, 737-748. https://doi.org/10.1016/S00456535(01)00117-5

Merten, G. H., Araújo, A. G., Biscaia, R. C. M., Barbosa, G. M. C., \& Conte, O. (2015). No-till surface runoff and soil losses in southern Brazil. Soil \& Tillage Research, 152, 85-93. https://doi.org/10.1016/j.still. 2015.03.014

Minella, J. P. G., Merten, G. H., \& Ruhoff, A. L. (2010). Utilização de métodos de representação espacial para cálculo do fator topográfico na equação universal de perda de solo revisada em bacias hidrográficas. Revista Brasileira de Ciência do Solo, 34, 1455-1462. https://doi.org/10.1590/S0100- 06832010000400041

Moraes, A., Carvalho, P. C. F., Anghinoni, I., Lustosa, S. B. C., Costa, S. E. V. G. A., \& Kunrath, T. R. (2014). Integrated crop-livestock systems in the Brazilian subtropics. European Journal of Agronomy, 57, 4-9. https://doi.org/10.1016/j.eja.2013.10.004

Ongley, E. D. (1996). Control of water pollution from agriculture. Food and Agriculture Org, Rome.

Ongley, E. D., Xiaolan, Z., \& Tao, Y. (2010). Current status of agricultural and rural non-point source pollution assessment in China. Environmental Pollution, 158, 1159-1168. https://doi.org/10.1016/j.envpol.2009.10. 047

Owens, L. B., Malone, R. W., Hothem, D. L., Starr, G. C., \& Lal, R. (2002). Sediment carbon concentration and transport from small watersheds under various conservation tillage practices. Soil and Tillage Research, 67, 65-73. https://doi.org/10.1016/S0167-1987(02)00031-4

Owino, J. O., Owido, S. F. O., \& Chemelil, M. C. (2006). Nutrients in runoff from a clay loam soil protected by narrow grass strips. Soil and Tillage Research, 88, 116-122. https://doi.org/10.1016/j.still.2005.05.007

Povilaitis, A., Sileika, A., Deelstra, J., Gaigalis, K., \& Baigys, G. (2014). Nitrogen losses from small agricultural catchments in Lithuania. Agriculture, Ecosystems \& Environment, 198, 54-64. https://doi.org/10.1016/j.agee. 2014.02.002

R Development Core Team. (2015). R: A language and environment for statistical computing. R Foundation for Statistical Computing. Retrieved from https:/www.r-project.org

Raclot, D., Bissonais, Y., Louchart, X., Andrieux, P., Moussa, R., \& Voltz, M. (2009). Soil tillage and scale effects on erosion from fields to catchment in a Mediterranean vineyard area. Agriculture, Ecosystems \& Environment, 134, 201-210. https://doi.org/10.1016/j.agee.2009.06.019

Ramos, M. R., Favaretto, N., Dieckow, J., Dedeck, R. A., Vezzani, F. M., Almeida, L., \& Sperrin, M. (2014). Soil, water and nutrient loss under conventional and organic vegetable production managed in small farms versus forest system. Journal of Agriculture and Rural Development in the Tropics and Subtropics, 115, 31-40.

Richardson, C. W., \& King, K. W. (1995). Erosion and nutrient losses from zero tillage on a clay soil. Journal of Agricultural Engineering Research, 61, 81-86. https://doi.org/10.1006/jaer.1995.1034 
SAGA (System for Automated Geoscientific Analyses). (2013). System for Automated Geoscientific Analyses, Version 2.1.0. Retrieved from http://www.saga-gis.org

Shan, L., He, Y., Chen, J., Huang, Q., Lian, X., \& Hang, H. (2015). Nitrogen surface runoff losses from a Chinese cabbage field under different nitrogen treatments in the Taihu Lake Basin. Agricultural Water Management, 159, 255-263. https://doi.org/10.1016/j.agwat.2015.06.008

Shiptalo, M. J., Dick, W. A., \& Edwards, W. M. (2000). Conservation tillage and macropore factors that affect water movement and the fate of chemicals. Soil and Tillage Research, 53, 167-183. https://doi.org/10.1016/ S0167-1987(99)00104-X

Smith, D. R., Warnemuende, E. A., Huang, C., \& Heathman, G. C. (2007). How does the first year tilling a long-term no-tillage field impact soluble nutrient losses in runoff? Soil and Tillage Research, 95, 11-18. https://doi.org/10.1016/j.still.2006.03.019

Sparks, D. L. (1996). Methods of soil analysis: Chemical methods. SSSA, Madison.

Sugamosto, M. L. (2002). Uso de técnicas de geoprocessamento para elaboração do mapa de aptidão agrícola e avaliação da adequação de uso do centro de estações experimentais do cangüiri, município de Pinhais-Paraná (Dissertation, Federal University of Parana, Brazil).

Vadas, P. A., \& Powell, J. M. (2013). Monitoring nutrient loss in runoff from dairy cattle lots. Agriculture, Ecosystems \& Environment, 181, 127-133. https://doi.org/10.1016/j.agee.2013.09.025

Vadas, P. A., Busch, D. L., Powell, J. M., \& Brink, G. E. (2015). Monitoring runoff from cattle-grazed pastures for a phosphorus loss quantification tool. Agriculture, Ecosystems \& Environment, 199, 124-131. https://doi.org/10.1016/j.agee.2014.08.026

Valeriano, M. M., \& Carvalho, O. A. J. (2003). Geoprocessamento de modelos digitais de elevação para mapeamento da curvatura horizontal em microbacias. Revista Brasileira de Geomorfologia, 4, 17-29. https://doi.org/10.20502/rbg.v4i1.17

Van de Giesen N., Stomph, T. J., \& Ridder, N. (2005). Surface runoff scale effects in West African watersheds: Modeling and management options. Agricultural Water Management, 72, 109-130. https://doi.org/10.1016/ j.agwat.2004.09.007

Veum, K. S., Goyne, K. W., Motavalli, P. P., \& Udawatta, R. P. (2009). Runoff and dissolved organic carbon loss from a paired-watershed study of three adjacent agricultural watersheds. Agriculture, Ecosystems \& Environment, 130, 115-122. https://doi.org/10.1016/j.agee.2008.12.006

Volk, L. B. S., Cogo, N. P., \& Streck, E. V. (2004). Erosão hídrica influenciada por condições físicas de superfície e subsuperfície do solo resultantes do seu manejo, na ausência de cobertura vegetal (in Portuguese). Revista Brasileira de Ciência do Solo, 28, 763-774. https://doi.org/10.1590/S0100-068320040 00400016

Wang, D., \& Laffan, S. W. (2009). Characterisation of valleys from DEMs. Paper presented at the meeting of 18th World IMACS/MODSIM Congress, Australia.

Yang, J. L., Zhang, G. L., Shi, X. Z., Wang, H. J., Cao, Z. H., \& Ritsema, C. J. (2009). Dynamic changes of nitrogen and phosphorus losses in ephemeral runoff processes by typical storm events in Sichuan Basin, Southwest China. Soil and Tillage Research, 105, 292-299. https://doi.org/10.1016/j.still.2009.04.003

\section{Copyrights}

Copyright for this article is retained by the author(s), with first publication rights granted to the journal.

This is an open-access article distributed under the terms and conditions of the Creative Commons Attribution license (http://creativecommons.org/licenses/by/4.0/). 